\title{
Seasonal leaf gas exchange and water potential in a woody cerrado species community
}

\author{
Carlos Henrique Britto de Assis Prado ${ }^{1 *}$, Zhang Wenhui ${ }^{2}$, Manuel Humberto Cardoza Rojas ${ }^{3}$ \\ and Gustavo Maia Souza ${ }^{4}$
}

\begin{abstract}
${ }^{1}$ Universidade Federal de São Carlos, Centro de Ciências Biológicas e da Saúde, Departamento de Botânica, CEP 13565-905, São Carlos, SP, Brasil; ${ }^{2}$ Tianjin Normal University, Biological Department, Tianjin, Weijin Road 241, 300074. P. R. China; ${ }^{3}$ Universidad Nacional de Piúra, Departamento de Agronomia, Apartado Postal 295, Piúra, Peru; ${ }^{4}$ Universidade de São Paulo, Escola Superior de Agricultura "Luiz de Queiroz", Departamento de Ciências Biológicas, Piracicaba, SP, Brasil. *Corresponding author: caique@power.ufscar.br Received: 20/09/2003, Accepted: 09/02/2004
\end{abstract}

Predawn leaf water potential ( $\Psi$ pd) and morning values of leaf gas exchange, as net photosynthesis (A), stomatal conductance (gs), transpiration (E), and morning leaf water potential ( $\Psi \mathrm{mn})$ were determined seasonally in 22 woody cerrado species growing under natural conditions. Despite the lower mean values of $\Psi$ pd in the dry season $(-0.35 \pm 0.23 \mathrm{MPa})$ compared to the wet season $(-0.08 \pm 0.03 \mathrm{MPa})$, the lowest $\Psi$ pd in the dry season $(-0.90 \pm 0.00 \mathrm{MPa})$ still showed a good nocturnal leaf water status recovery for all species studied through out the year. Mean gs values dropped $78 \%$ in the dry season, when the vapor pressure of the air was $80 \%$ greater than in the wet season. This reduction in gs led to an average reduction of $33 \%$ in both $\mathrm{A}$ and $\mathrm{E}$, enabling the maintainance of water use efficiency (WUE) during the dry season. Network connectance analysis detected a change in the relationship between leaf gas exchange and $\Psi \mathrm{mn}$ in the dry season, mainly between gs-E and E-WUE. A slight global connectance value increase $(7.25 \%)$ suggested there was no severe water stress during the dry season. Multivariate analysis showed no link between seasonal response and species deciduousness, suggesting similar behavior in remaining leaves for most of the studied species concerning leaf gas exchange and $\Psi \mathrm{mn}$ under natural drought.

Keywords: cerrado, deciduousness, network connectance, stomatal conductance, photosynthesis.

Sazonalidade das trocas gasosas e do potencial hídrico foliar em uma comunidade de espécies lenhosas de cerrado: Os potenciais de água foliar antes do amanhecer ( $\Psi$ pd) e matinais $(\Psi \mathrm{mn})$, e as trocas gasosas (fotossíntese líquida - A, condutância estomática - gs, e transpiração - E) foram determinados sazonalmente em uma comunidade de cerrado composta por 22 espécies lenhosas crescendo sob condições naturais. Embora os valores médios de $\Psi$ pd tenham sido menores na estação seca (-0,35 $\pm 0,23 \mathrm{MPa})$ do que na estação chuvosa (-0,08 \pm 0,03 MPa), o menor valor de $\Psi$ pd na estação seca (-0,90 $\pm 0,00 \mathrm{MPa})$ ainda indicou boa recuperação noturna do estado hídrico em todas as plantas estudadas durante o ano. $\mathrm{O}$ valor médio de gs decresceu $78 \%$ na estação seca, a qual apresentou um déficit de pressão de vapor do ar $80 \%$ maior que a da estação chuvosa. Essa redução de gs causou uma redução média de cerca de 33\% de A e E na comunidade, possibilitando a manutenção da eficiência do uso da água durante a seca. Mediante análise da conectância de redes foi possível detectar alterações nas relações entre os parâmetros de trocas gasosas e $\Psi \mathrm{mn}$ sob seca, principalmente entre gs-E e E-WUE. Um pequeno aumento na conectância global do sistema (7,25 \%) sugeriu ausência de estresse ambiental severo sob seca. A análise multivariada não mostrou uma relação entre resposta sazonal e deciduidade das espécies, indicando um comportamento similar nas folhas remanescentes para a maioria dos indivíduos estudados em relação às trocas gasosas e variações do potencial de água foliar na estação seca.

Palavras-chave: cerrado, condutância estomática, conectância de rede, deciduidade, fotossíntese. 


\section{INTRODUCTION}

The Cerrado biome accounts for large area (around 2,000.000 $\mathrm{km}^{2}$, similar in size to Western Europe - Ratter et al., 1997) and has the greatest number of wild plant species $(6,429$ in number - Mendonça et al., 1998) among the neotropical savannas. Excluding the vines, there are at least 1,753 woody species growing in different cerrado physiognomies (Castro, 1994) under a clear seasonal rainfall regime (Nix, 1983; Franco, 2002). Many woody cerrado species lose their leaves partially or totally during winter dry season (Rizzo et al., 1971; Barros and Caldas, 1980; Dutra, 1987; Oliveira, 1998; Paula, 2002) indicating a close link between drought and deciduousness.

Previous studies concerning water balance carried out in cerrado vegetation concluded there was no stomatal control of the transpiration in most of woody species observed during dry season (Ferri, 1944; Rawistscher, 1948; Ferri, 1955; Grisi, 1971; Goodland and Ferri, 1979). On the other hand, since the eighties, many studies have demonstrated that the opposite situation was more realistic with regard to the link between the leaf transpiration and stomatal conductance in woody cerrado species under natural drought (Johnson et al., 1983; Moraes et al., 1989; Perez and Moraes, 1991; Mattos et al., 1997). Actually, in the dry season, there is a dop in leaf gas exchange along the day (Moraes and Prado, 1998; Franco, 1998), and a close link between diurnal stomatal conductance and sap flow in woody cerrado species (Naves-Barbiero et al., 2000).

Therefore, from all recent investigations it is possible to conclude that during the dry season the remaining leaves were able to strongly influence the control over the short term plant water balance, adjusting transpiration as a function of plant hydraulic limitations in view of a rise in atmosphere air vapor pressure deficit and superficial soil dehydration. It could maintain instantaneous water use efficiency (photosynthesis/ transpiration ratio), and leaf water balance as positive as possible after the peak of leaf gas exchange in early morning (Franco, 1998; Moraes and Prado, 1998; Meinzer, et al., 1999; Naves-Barbiero et al., 2000). Because good nocturnal water status recovery in woody stricto sensu cerrado species throughout the year (Mattos et al., 1997; Meinzer et al., 1999) a more pronounced water stress occurs only after early morning, when air vapor saturation deficit rises rapidly (Franco, 1998).

All these recent investigations were carried out focusing on plant species instead of community responses. Results such as leaf-air gas exchange, sap flow, and leaf water potential were reported to be correlated with each other or with an environmental parameter such as air vapor pressure deficit (Moraes and Prado, 1998; Meinzer et al., 1999; Naves-Barbiero et al., 2000). On the other hand, often only few species were utilized and the link between leaf responses under drought (such as gas exchange and water potential) and deciduousness is absent. Recently, Amzalag (2001) proposed new tools of analysis that permit the establishment of a network of regulatory physiological parameters. These tools (specially connectance) opened new perspectives in understanding plant non-linear processes involved in its regulation and the coordinated changes of the network under stress.

In this study, the morning values (between 10:00-11:30 h) of leaf gas exchange and leaf water potential were determined in a plant community represented by 22 woody stricto sensu cerrado species growing under natural conditions in dry and wet seasons. It was determined whether the drop in stomatal conductance during the dry season was able to maintain water use efficiency and, at the same time, hold the leaf water status after early morning. Values of predawn leaf water potential in dry and wet seasons were also determined in order to confirm suitable nocturnal leaf water status recovery in the community throughout the year. By network analysis (Amzallag, 2001), potential changes in modulation of the gas exchange between seasons were investigated. Furthermore, a multivariate analysis of the community data enabled us to test the hypothesis that gas exchange alterations on the remaining leaves in the dry season could be related to a specific deciduousness.

\section{MATERIALS AND METHODS}

Study area, climate, and the period of measurements during the year: All individuals were adult and growing in the same hectare of cerrado stricto sensu physiognomy of São Carlos Federal University reserve. This study area is located in the Southeast of Brazil, São Paulo State, in the municipality of São Carlos (22 $00^{\prime}-22^{\circ} 30^{\prime} \mathrm{S}$ and $\left.47^{\circ} 30^{\prime}-48^{\circ} 00^{\prime} \mathrm{W}\right)$, and typically presents one month without rainfall during the winter (Tolentino, 1967). Taking into account the Koeppen climatic classification, this region is between Aw and Cwa (Tolentino, $1967)$ with mean \pm standard deviation temperature values recorded from 1988 to 2000 of $15.9 \pm 2.1^{\circ} \mathrm{C}$ (minimum), 21.3 $\pm 2.3^{\circ} \mathrm{C}$ (average), and $26.9 \pm 2.1^{\circ} \mathrm{C}$ (maximum). The same individuals identified in January 1996 were utilized in the wet (April 1996) and dry (August and September 1997) seasons. 
Why carry out measurements between 10:00-11:30 h?: Extreme values of air vapor pressure deficit (VPD) were avoided during gas exchange measurements in both the dry and wet seasons. Low values of VPD in early morning or high VPD values between 12:00-14:00 p.m. could strongly reduce the influence of other environmental or physiological factors on leaf gas exchanges, leading to similar A, gs, and $\mathrm{E}$ values in dry or wet seasons. This occurs because VPD values have much influence over leaf gas exchange in woody cerrado species subjected to soil dehydration or not (Prado and Moraes, 1994; Franco 1998; Meinzer et al. 1999).

Early morning is the most favorable time of day to measure leaf gas exchange in woody species due to nocturnal water status recovery and low VPD values (Eamus et al., 1999; Larcher, 2003). Woody stricto sensu cerrado species were able to recover leaf water status during the night, even in dry seasons (Mattos et al., 1997; Meinzer et al., 1999). Thus, leaf gas exchanges before 10:00 a.m. are potentially the same in wet or in dry seasons. For instance, Moraes and Prado (1998) found similar rates of A, E and gs around 8:00 a.m. in Bauhinia holophylla and Eriotheca gracilipes in dry or wet seasons under similar PPFD values.

On the other hand, reduced and similar gas exchange values in woody stricto sensu cerrado species could occur at midday throughout the year, due to stressful atmospheric conditions (high VPD values) at this time of the day as well as to plant hydraulic constraints. Franco (1998) recorded lower or same gs and A values at 13:00 p.m. during the wet season in relation to those obtained at the same hour in the dry season (both under PPFD $=1500 \mu \mathrm{mol} \mathrm{m}^{-2} \mathrm{~s}^{-1}$ and VPD $=2.5 \mathrm{kPa}$ ) in Roupala montana. Prado and Moraes (1994) observed a marked drop in A and gs values in the leaves of potted young plants of Copaifera langsdorffii showing favorable leaf water status $(\Psi \mathrm{pd}=-0.6 \mathrm{MPa})$ but under the stress conditions imposed by the cerrado stricto sensu atmosphere around midday $(\mathrm{VPD}=3.6 \mathrm{kPa})$. Hence, leaf gas exchange around midday during the wet season did not show differences related to those obtained in the dry season due to A, gs and $\mathrm{E}$ depression being conditioned by high VPD.

Conspicuous differences in leaf gas exchange between seasons may occur after early morning and before midday. At this time (e.g. 10:00-11:30 a.m.) the VPD values between seasons should be different (lower values in wet season) but the extreme VPD values are avoided allowing greater differences in A, gs, and E between seasons. Potential seasonal changes in modulation of the gas exchange network could be easily revealed searching for these higher differences in morning values of $\mathrm{A}, \mathrm{gs}$, and $\mathrm{E}$. Therefore, the period between 10:00-11:30 a.m. was chosen to depict seasonal leaf gas exchange differences and their relationships (network modulation) in woody stricto sensu cerrado species.

Number of individuals and leaves chosen: Since this study takes into account seasonal changes at the community level, each measurement taken for each individual plant was considered as a replicate of the community elements in each season. Thus, one individual per species was measured and the average value of leaf gas exchange in each species was calculated after two measurements, each one in different leaves or leaflets in same individual. The leaves chosen were totally expanded without signs of senescence or damage, and exposed directly to solar radiation (sun leaves). Three sun leaves or leaflets were detached from the same individual in order to obtain the average of morning ( $\Psi \mathrm{mn})$ or predawn ( $\Psi$ pd) leaf water potential values. As in leaf gas exchange measurements, the same marked individual of each species was utilized in the wet and dry seasons.

Measurements of morning leaf gas exchange and leaf water

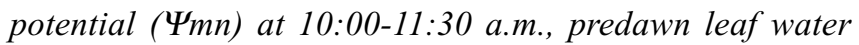
potential ( $\Psi p d)$, and meteorological data registration: Leaf gas exchange measurements such as net photosynthesis (A), stomatal conductance (gs), transpiration (E), and atmosphere (Ca) and intercellular ( $\mathrm{Ci}) \mathrm{CO}_{2}$ concentration, were carried out under natural conditions using a portable infrared gas analyzer (IRGA, model LCA-2, ADC, Hoddesdon, UK). The IRGA was connected to a data logger (DL-2, ADC), a Parkinson Leaf chamber (PLC-2, ADC) and a digital external pump (ASUM-2, ADC). Water use efficiency (WUE) was calculated dividing A by the E value (Larcher, 2003). The Ci/ $\mathrm{Ca}$ ratio was considered as a reference to indicate the possible drop in $\mathrm{CO}_{2}$ sub stomatal availability in the dry season (Ehleringer, 1995). The $\Psi$ pd and $\Psi \mathrm{mn}$ were measured utilizing a pressure chamber (model 3005, Santa Barbara soil moisture, Santa Barbara, USA).

Meteorological data (monthly rainfall and air temperature values) were obtained from the national meteorological station number $83726,3.0 \mathrm{~km}$ away from the area where the woody species were growing. Air vapor pressure deficit (VPD) mean values in both dry and wet seasons were calculated as proposed by Jones (1992), using air relative humidity and air temperature recorded by a strand hair thermo-hygrograph (Füess, Berlin-Steglitz, Germany) at the meteorological station 83726 , at 10:00, 11:00 and 12:00 $\mathrm{h}$. 
In order to avoid overheating; the PLC-2 was covered with aluminum foil during gas exchange measurements. Only the PPFD sensor and the transparent window exposing the leaf to PPFD of PLC-2 were uncovered. The external air pump ASUM-2 worked at $400 \mathrm{ml} \mathrm{min}{ }^{-1}$ free of silica in both columns, maintaining the same ambient air relative humidity before the PLC-2.

Leaf phenology assessment: Leaf phenology was estimated monthly for Didymopanax vinosum, Erythroxylum suberosum, and Styrax camporum during 1996, 1997, and 2003. Paula (2002) recorded in the same study area the leaf phenology of the rest of the woody species studied during 2001-2002 at intervals of 15 days (table 1). In both cases three to five individuals were observed. The reduction in canopy fullness on a percentage basis was estimated visually and the categorization adopted was that proposed by Williams et al. (1997) for Australian savanna woody species, with some modifications pointed out by Paula (2002), as followed.
Species were considered evergreen when individuals maintained more than $90 \%$ of their leaves through the year. Brevideciduous species show regular seasonal drop in canopy fullness less than $50 \%$ in dry season, while for semideciduous species this value is greater than $50 \%$. Species were considered deciduous if they were free of leaves in the dry season, even if only for a few days.

Data analyses: Multivariate principal components analysis (PCA) was used in order to evaluate the community response variability in relation to dry and wet seasons. The PCA is a linear dimensionality reduction technique, which identifies orthogonal directions of maximum variance in the original data, and projects the data into a lower-dimensionality space formed of by sub-set of the highest-variance components (Manly, 1994). In this study a space of two dimensions (two main components), which was limited by two axes labeled $\mathrm{pc} 1$ and $\mathrm{pc} 2$, was suitable for our analysis. The PC-ORD version 3.12 software (MJM Software Design, Gleneden Beach, Oregon, USA) was used.

Table 1. Species studied and their deciduousness (DN), sensu Williams et al. (1997) and after Paula (2002): EV, evergreen; $\mathrm{BD}$, brevideciduous; SD, semideciduous; and DE, deciduous. The three letters in parenthesis after the species name are the abbreviations utilized in figure 3. Both deciduous species ( 3 and 4 ) are free of leaves for a maximum of 20 days (Paula, 2002). Authors determined the species 7, 11 and 21 deciduousness during 1996, 1997, and 2003.

\begin{tabular}{|c|c|c|c|c|}
\hline & & Species & & DN \\
\hline 1 & Annona coriacea (Aco) & Anonaceae & Mart. & $\mathrm{BD}$ \\
\hline 2 & Bahuinia rufa (Bru) & Caesalpiniaceae & (Bongard) Stendel & $\mathrm{DE}$ \\
\hline 3 & Campomanesia xanthocarpa (Cxa) & Myrtaceae & Berg. & $\mathrm{DE}$ \\
\hline 4 & Casearia sylvestris (Csy) & Flacourtiaceae & S.W. & SD \\
\hline 5 & Connarus suberosus $(\mathrm{Csu})$ & Connaraceae & Planch. & EV \\
\hline 6 & Copaifera langsdorffii (Cla) & Caesalpiniaceae & Desf. & SD \\
\hline 7 & Didymopanax vinosum (Dvi) & Araliaceae & Cham. \& Schlecht & EV \\
\hline 8 & Duguetia furfuracea (Dfu) & Anonaceae & (St. Hill) Benth. \& Hook. & $\mathrm{EV}$ \\
\hline 9 & Eriotheca gracilipes $(\mathrm{Egr})$ & Bombacaceae & (K. Schum)A. Robyns & SD \\
\hline 10 & Erythroxylum campestre (Eca) & Erythroxylaceae & A. St. Hill & SD \\
\hline 11 & Erythroxylum suberosum (Esu) & Erythroxylaceae & St. Hill & SD \\
\hline 12 & Gochnatia floribunda (Gfl) & Asteraceae & Cabrera & SD \\
\hline 13 & Memora axillaris (Max) & Bignoniaceae & Bureau \& K. Schum & SD \\
\hline 14 & Miconia albicans $(\mathrm{Mal})$ & Melastomataceae & (Sw.) Triana & EV \\
\hline 15 & Miconia ligustroides (Mli) & Melastomataceae & (DC.) Naud & EV \\
\hline 16 & Piptocarpha rotundifolia (Pro) & Asteraceae & (Less) Baker & $\mathrm{EV}$ \\
\hline 17 & Roupala montana $(\mathrm{Rmo})$ & Proteaceae & Aubl. & $\mathrm{BD}$ \\
\hline 18 & Solanum lycocarpum (Sly) & Solanaceae & St. Hill & SD \\
\hline 19 & Stryphnodendron adstringens $(\mathrm{Sad})$ & Mimosaceae & (Mart.) Cov. & SD \\
\hline 20 & Stryphnodendron obovatum (Sob) & Mimosaceae & Benth. & $\mathrm{BD}$ \\
\hline 21 & Styrax camporum (Sca) & Styracaceae & Pohl & $\mathrm{EV}$ \\
\hline 22 & Tibouchina stenocarpa $(\mathrm{Tst})$ & Melastomataceae & (DC.) Cogn. & SD \\
\hline
\end{tabular}


Changes in gas exchange network connectance were evaluated according to Amzallag (2001) and Souza et al. (2004). Gardner and Ashby (1970) defined connectance as a quantifying parameter of the level of linkage within a system. Herein, connectance value (z) represents the relationship strength between two parameters previously quantified in the community according to the network proposed in figure 2 ( $\Psi \mathrm{mn}-\mathrm{E}$, gs-Ci/Ca, gs-A, gs-E, Ci/Ca-A, WUE-A, and WUEE relationships). These relationships were based on a previous gas exchange network model used by Souza et al. (2004), adapted from Jones (1998). As suggested by Amzallag (2001), since linear correlation coefficients (r-values) have a complex variation, $r$ values cannot serve as parameters for further calculations. However, these calculations are possible after $\mathrm{z}$-transformation of the $\mathrm{r}$ coefficients, because $\mathrm{z}$ is normally distributed. Thus, connectance (z-values) were calculated as $\mathrm{z}=0.5 \ln [(1+|\mathrm{r}|) /(1-|\mathrm{r}|)]$ (Sokal and Rohlf, 1981). The network global connectance $(\mathrm{Cg})$ was calculated as the mean of the total connectance of paired parameters (Amzallag, 2001). Cg value represents the level of global coordination of leaf gas exchanges and water potential network.

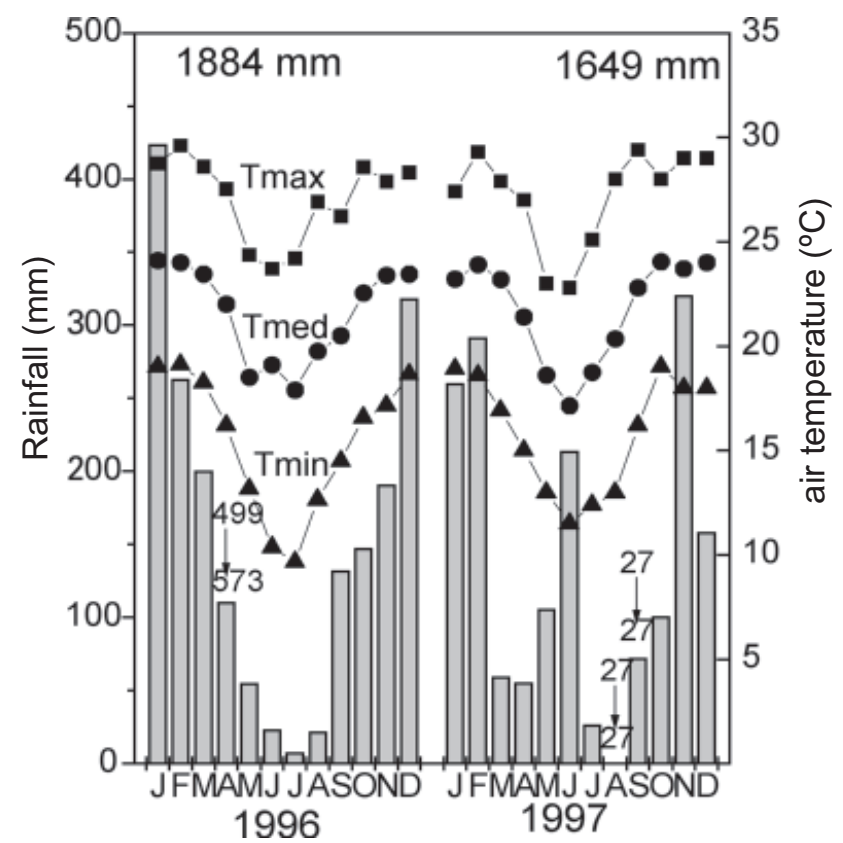

Figure 1. Monthly rainfall (bars) together with maximum, medium and minimum mean air temperature values (Tmax, Tmed, and Tmin, respectively). The arrow above bars indicates the months when the measurements were carried out and the numbers above and below arrows represent the total 60 -day rainfall $(\mathrm{mm})$ accumulated at the beginning (upper number) and at the end (lower number) over the period of leaf gas exchange and water potential measurements. The total rainfall in each year is depicted at the top of the figure.

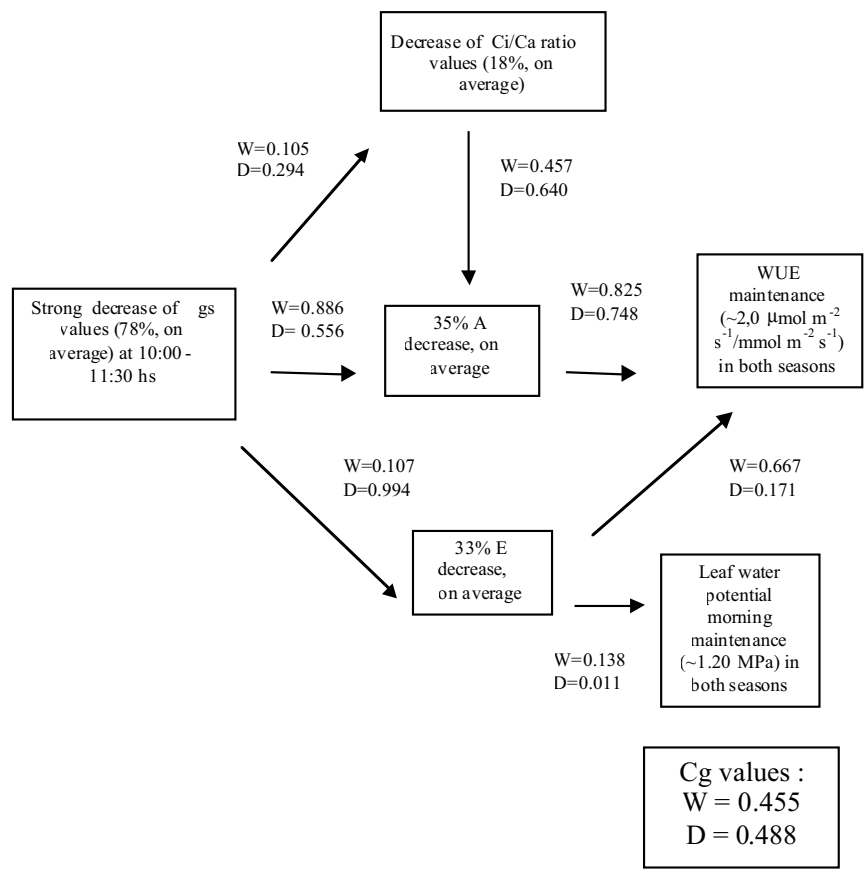

Figure 2. Diagrammatic representation depicting the relationships among the main results obtained in the dry season for the 22 woody cerrado species growing in a community under natural conditions. Arrows linking the frames represent causal relationships. The connectance values ( $\mathrm{z}$ values) in wet (W) and in dry (D) seasons were shown for the relationships between paired parameters linked by arrows, based upon results in table 4 . The global network connectance values (Cg values) for both seasons are shown in the bottom right (thick) frame.

\section{RESULTS AND DISCUSSION}

Meteorological conditions: Figure 1 summarizes the rainfall distribution during the year, showing typical wet and dry seasons found in neotropical savannas (Nix, 1983). In 1996 some rainfall was registered during winter months (June, July and August), and in 1997 only August was free from rainfall. In the core region of the Cerrado biome (near Brasília city) the winter drought months are usually more intense, showing 2 or 3 months without rainfall (Franco, 2002). Some studies carried out in Brasília showed a significant drop in soil water potential $(\Psi \mathrm{s})$ only during the months free from rainfall (usually between July and September) when $\Psi$ s values reached -1.5 MPa in layers above $0.85 \mathrm{~m}$ (Franco et al., 1996; Franco, 1998; Franco, 2002). The atmosphere $\mathrm{CO}_{2}$ concentration and air temperature mean values were similar between seasons (table 2), and averages of PPFD values were same or higher than that necessary to saturate net photosynthesis of 20 woody stricto sensu cerrado species studied by Prado and Moraes (1997). Atmosphere vapor pressure deficit (VPD) was $80 \%$ higher in the dry season (1.8 $\mathrm{kPa})$ compared to that in the wet season $(1.0 \mathrm{kPa})$, potentially increasing the transpiration under winter drought. 
In table 3 the days of the month are listed when the morning leaf gas exchange and water potential were carried out together with the accumulated total rainfall values over the 60 days preceding each measurement day. Accumulated rainfall in the dry season was 20 times lower than in the wet season.

Table 2. Mean \pm standard deviation values of meteorological conditions during morning (10:00-11:30 a.m.) leaf gas exchange and leaf water potential measurements in wet (April, 1996) and dry (August, and September 6, 1997) seasons. PPFD = photosynthetic photon flux density, VPD $=$ vapor pressure deficit.

\begin{tabular}{ccc}
\hline $\begin{array}{c}\text { Atmospheric } \\
\text { conditions }\end{array}$ & $\begin{array}{c}\text { Wet season } \\
\text { (April, 1996) }\end{array}$ & $\begin{array}{c}\text { Dry season } \\
\text { (August and } \\
\text { September 6, 1997) }\end{array}$ \\
\hline PPFD $\left(\mu \mathrm{mol} \mathrm{m}{ }^{-2} \mathrm{~s}^{-1}\right)$ & $1143 \pm 125$ & $1435 \pm 145$ \\
Air temperature $\left({ }^{\circ} \mathrm{C}\right)$ & $22.9 \pm 1.9$ & $23.9 \pm 1.7$ \\
VPD $(\mathrm{kPa})$ & $1.0 \pm 0.3$ & $1.8 \pm 0.4$ \\
Atmosphere $\mathrm{CO}_{2}(\mathrm{ppm})$ & $336 \pm 3.4$ & $338 \pm 3.9$ \\
\hline
\end{tabular}

Table 3. Seasons, months and the days of measurements during 1996-1997. The total accumulated rainfall (mm) during the 60 days preceding each measurement day are shown in parenthesis.

\begin{tabular}{cc}
\hline $\begin{array}{c}\text { Seasons and months } \\
\text { of measurements }\end{array}$ & $\begin{array}{c}\text { Day of measurement, and } \\
\text { the total rainfall accumulated }\end{array}$ \\
\hline Wet season. & 60 days before (in parenthesis) \\
April, 1996 & $10(499) ; 13(553) ; 14(553) ;$ \\
$15(554) ; 16(557) ;$ \\
$18(573) ; 22(573)$ \\
Dry season. \\
August and 6 September, 1997
\end{tabular}

Values of $\Psi p d, \Psi m n, g s, A, E, W U E$ and the Ci/Ca ratio: The mean values of $\Psi \mathrm{pd}, \Psi \mathrm{mn}$, gs, A, E, WUE and the $\mathrm{Ci} / \mathrm{Ca}$ ratio in the wet and dry seasons for the studied plant community are listed in table 4 . During the dry season, the mean values of $\Psi \mathrm{pd}, \mathrm{A}, \mathrm{E}$, gs and $\mathrm{Ci} / \mathrm{Ca}$ showed a downward trend at the community level. However, some species were more affected than others by environmental changes. For instance, while $D$. vinosun showed minimal alterations in a number of physiological parameters, species such as $R$. montana, C. suberosus, and G. floribunda were markedly affected by seasonal changes (table 4).

Despite the downward trend in $\Psi$ pd values in the dry season, the lowest mean value obtained in Gochnatia floribunda $(-0.90 \pm 0.00 \mathrm{MPa})$ did not represent an unfavorable predawn leaf water stress situation during winter drought. Prior et al. (1997) considered that the $\Psi$ pd values below $-0.50 \mathrm{MPa}$ for North Australian Savannas woody species indicated the initial transitional stage $(-0.50 \geq \Psi \mathrm{pd} \geq$ - 1.5 MPa) to a severe leaf water stress situation ( $\Psi \mathrm{pd}<-1.5$ $\mathrm{MPa})$. This water unstressed leaf predawn condition revealed by high $\Psi$ pd values was confirmed by other studies with woody stricto sensu cerrado species growing under natural environment. Mattos et al. (1997) recorded -0.50 MPa to Annona coreaceae and -0.70 MPa for Rapanea umbellata as $\Psi$ pd values in the dry season. Franco (1998) obtained -0.40 $\mathrm{MPa}$ for Roupala montana in Brasilia despite 3 months with no rainfall. In addition, values between -0.35 and $-0.58 \mathrm{MPa}$ were registered in 3 woody evergreen species during the dry season in Brasília and the differences between wet and dry seasons were not greater than $-0.25 \mathrm{MPa}$ (Meinzer et al., 1999). Therefore, these $\Psi$ pd values indicate that at least an important part of the rhizosphere woody stricto sensu cerrado species works under favorable water availability and they could initiate the early morning leaf gas exchange activity at full capacity throughout the year.

Among 22 species of the community only 3 species showed greater E dry season morning values: Annona coriaceae, Didymopanax vinosum, and Solanum licocarpum. On the other hand, all species presented a trend towards lower gs values under drought (table 4 and figure 2). In view of a strong gs mean value drop (-78 \%) a reduction in E (-32\%) was possible, helping to maintain the morning leaf water status in the dry season under VPD values $80 \%$ greater than in the wet period (figure 2). This indicates that sensitive control of transpiration could be carried out by narrowing the stomatal pore and disagrees with the free transpiration hypothesis first reported concerning water balance in woody cerrado species (Ferri, 1944; Rawistscher, 1948; Ferri, 1955; Grisi, 1971; Goodland and Ferri, 1979).

The $\mathrm{A}$ and $\mathrm{E}$ rates were equally reduced ( -35 and $-33 \%$, respectively) in the dry season which allows the maintenance of WUE mean value around $2.0 \mu \mathrm{mol} . \mathrm{m}^{-2} . \mathrm{s}^{-1} / \mathrm{mmol} \cdot \mathrm{m}^{-2} \cdot \mathrm{s}^{-1}$ in both seasons (table 4 and figure 2). These results showed a close relationship between water and carbon balances in the dry season. Thus, natural drought caused significant alterations in the leaf gas exchange pattern, maintaing similar $\Psi \mathrm{mn}$ and WUE values between seasons. Therefore, $\Psi \mathrm{mn}$ and WUE could play some function in network leaf gas exchange control as a reference for maintaining proportional rates of gs, E, and A under drought. 


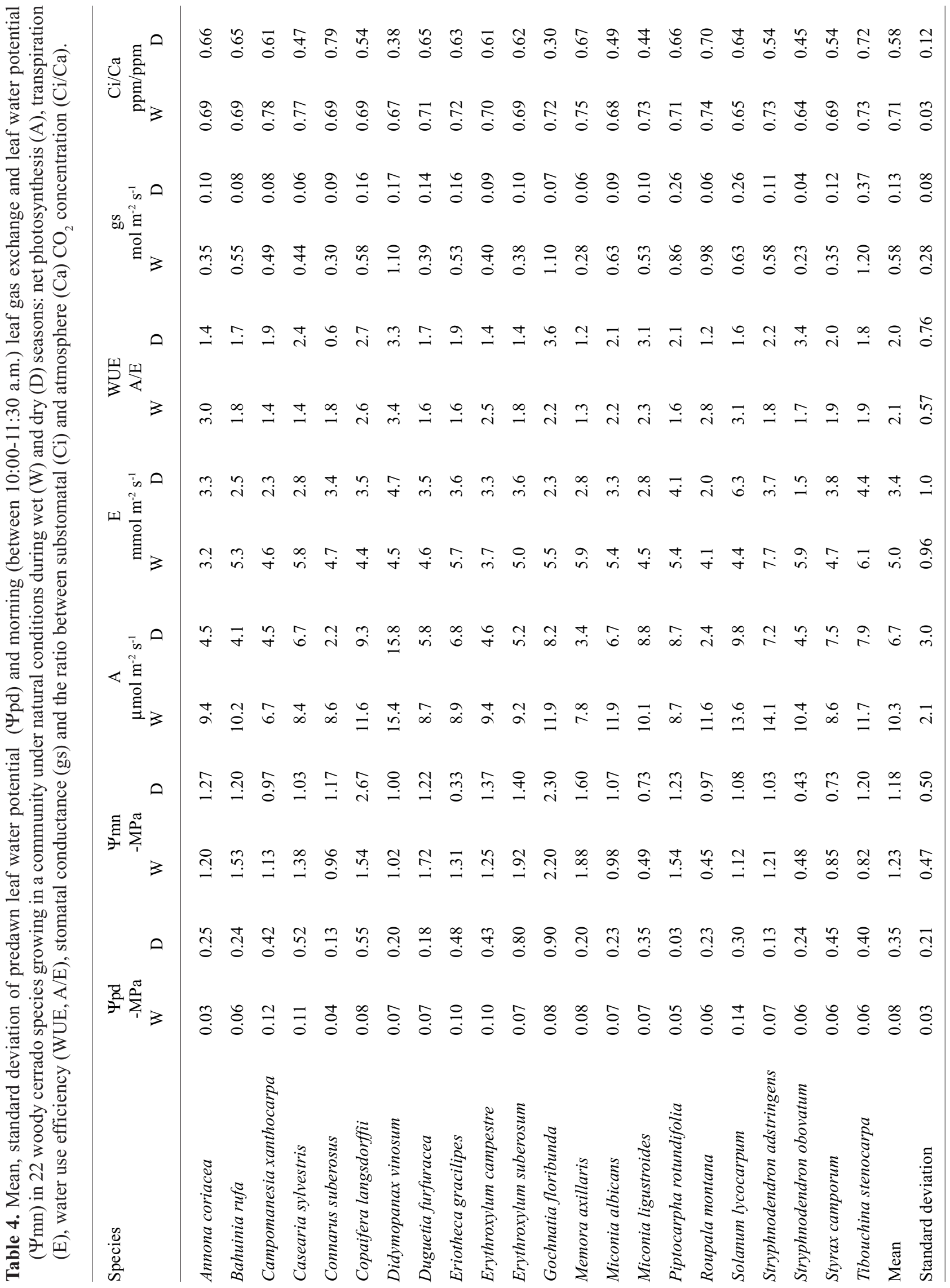


According to Nobel (1999), partial stomatal closure is more effective to constrain water vapor loss to the atmosphere than incoming $\mathrm{CO}_{2}$ for physicochemical reasons (greater $\mathrm{H}_{2} \mathrm{O}$ than $\mathrm{CO}_{2}$ diffusion coefficient and shorter $\mathrm{H}_{2} \mathrm{O}$ route for the atmosphere). However, extreme stomatal pore narrowing under drought promotes high resistance to $\mathrm{CO}_{2}$ sub stomatal diffusion, reducing both $\mathrm{CO}_{2}$ availability to carboxylation and $\mathrm{Ci} / \mathrm{Ca}$ values (Ehleringer, 1995). Our results suggested that this probably occurred in the species under drought, since a strong drop in gs $(-78 \%)$ and a significant reduction in $\mathrm{Ci} / \mathrm{Ca}$ values from the wet $(0.71 \pm 0.03 \mathrm{ppm} / \mathrm{ppm})$ to the dry $(0.58 \pm$ $0.12 \mathrm{ppm} / \mathrm{ppm}$ ) season (table 4) were observed. Simultaneously, it could cause low $\mathrm{CO}_{2}$ partial pressure in the sub-stomatal chamber, reducing carboxylation capacity and lowering A rates (-35\%). Summarizing, strong gs morning drop indicated that all studied species showed stomatal narrowing in the dry season and it could be considered a causal event of $\mathrm{Ci} / \mathrm{Ca}$ and leaf gas exchange reduction.

Diagrammatic representation of the relationship among the main results observed in dry season; connectance (z) and global network connectance (Cg) in dry and wet seasons: In view of the remarkable differences between wet and dry season mean values (table 4), a diagrammatic representation was proposed between leaf gas exchange and $\Psi \mathrm{mn}$ values in the dry season, pointing out the main causal events and their likely physiological consequences after early morning (figure 2). The greatest alteration in $z$ values (connectance) occurred in relation to gs-E and E-WUE relationships. In the wet season gs-E and E-WUE connectances were 0.107 (a non significant correlation, $\mathrm{p}>0.05$ ) and 0.667 (a significant correlation, $\mathrm{p}$ $<0.05$ ), respectively. Contrasting, gs-E and E-WUE z values were, in that order, 0.994 (a very significant correlation, $\mathrm{p}<$ 0.01 ) and -0.171 (a non significant correlation, $p>0.05$ ), in the dry season. Thus, the greater control of gs upon E may have been effective for the maintenance of $\Psi \mathrm{mn}$ in dry season by reducing water loss to atmosphere (Cornic, 2000; Chaves et al., 2002). However, the very low connectance between $\mathrm{E}$ and $\Psi \mathrm{mn}$ (figure 2) suggested other mechanisms could be involved for the maintenance of $\Psi \mathrm{mn}$, such as osmotic adjustment (Moraes and Prado, 1998; Hare et al., 1998; Chaves et al., 2002).

The higher $z$ value of A-WUE (0.748) than E-WUE $(0.117)$ in dry season suggests that WUE maintenance was much more conditioned by variations in $\mathrm{CO}_{2}$ assimilation (A $\mathrm{CV}=44.78)$. The slightly higher dry season $\mathrm{Cg}$ value $(0.488)$ indicated a trend to a greater network control in this season than in the wet season, which could mean a more strict leaf gas exchange control under drought for the maintenance of $\Psi \mathrm{mn}$ and WUE. However, this slight Cg increase (7.25\%) in the dry season indicated that probably there was not a significant drought stress effect on the community. Increases in network connectance may be considered as an effective response of biological systems to cope with environmental disturbances (Trewavas, 1986; Edelman and Gally, 2001). Souza and Oliveira (2003, unpublished data) and Souza et al. (2004) observed that higher $\mathrm{Cg}$ values showed a straightforward relationship with homeostatic capacity of plants under water deficit.

Principal component analyses (PCA): The PCA (figure 3) showed a clear separation between dry and wet seasons, considering the distribution through the first principal component (pc1), which accounted for $47.3 \%$ of total data variance. The second and fourth quadrants were occupied only by the studied species in the dry season. In addition, taking into account the distribution in relation to second principal component ( $\mathrm{pc} 2$ ), it was possible to detect that symbols representing the species were more disperse in the second and fourth quadrants (dry season). The physiological parameters that played a more significant role to separate the species in relation to $\mathrm{pc} 1$ were ranked in order of importance: gs, E, $\Psi \mathrm{pd}, \mathrm{Ci} / \mathrm{Ca}, \mathrm{A}, \mathrm{WUE}$, and $\Psi \mathrm{mn}$. On the other hand, the more significant physiological parameters to separate the species along pc2, which accounted for $23.4 \%$ of total data variance, were: WUE, A, Ci/Ca followed by gs, $\Psi$ pd, E and $\Psi \mathrm{mn}$, in decreasing order.

The PCA results revealed it was not possible to recognize a relationship between species deciduousness and their spatial distribution on quadrants in wet or in dry seasons. It suggests that there was no relationship between leaf phenology and morning leaf water status or gas exchange during the year. Thus, distinct leaf shedding intensity could represent only how much leaf area each species needs to lose in order to keep transpiration in pace with water extraction and water lift capacity in the dry season. After shedding, the remaining leaves tend to respond in the same way under drought despite species deciduousness, prevailing a general behavior for leaf gas exchange and leaf water status maintenance. Besides, the effect at the community level was evident, since through the graphical observation it was possible to distinguish a clear separation between seasons. Nevertheless, it is important to take into account that this observable separation probably not due to a stressful condition, since neither the $\Psi$ pd values were representative of a strong water constrain nor did the $\mathrm{Cg}$ 
analysis indicated a remarkable environment influence on network regulation.

On the other hand, there was a more variable response among species in dry season, as displayed by greater dispersion on the second and fourth quadrants (figure 3). It indicates that the aforementioned general behavior does not mean the same intensity response for all studied species under drought, especially when considering the parameters WUE and $\mathrm{A}$, which showed higher importance for dispersing the species in relation to $\mathrm{pc} 2$.

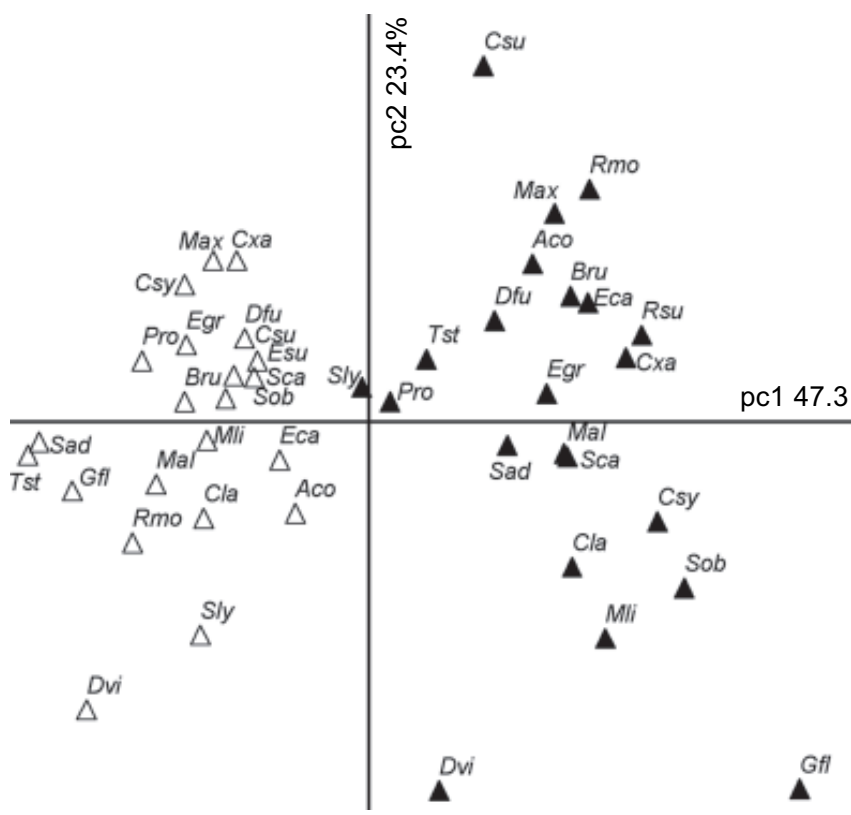

Figure 3. Species distribution for first and second principal components (pc1 and pc2 axes, respectively). White triangles represent the species of the community in the wet season and black triangles represent the community in the dry season. This striking arrangement separating wet and dry seasons (left and right side, respectively) were carried out using the physiological parameters described in table 4. Species name abbreviations are shown in table 1 .

Acknowledgments: Some of the results presented were gathered and well thought-out with support from FAPESP (95/00638-5), CNPq-Pronex (76.97.1066.00), and CAPES (China-Capes agreement). We are grateful to Univerversidade Nacional de Piura, and PPG-ERN for supporting MHCR.

\section{REFERENCES}

Amzallag GN (2001) Data analysis in plant physiology: are we missing the reality? Plant Cell Environ. 24:881-890.

Barros MAG, Caldas LS (1980) Acompanhamento de eventos fenológicos apresentados por cinco gêneros nativos do cerrado (Brasília-DF). Bra. Flor. 10:7-13.
Castro AAJF (1994) Comparação florística-geográfica (Brasil) e fitossociológica (Piauí -São Paulo) de amostras de Cerrado. Campinas, Universidade Estadual de Campinas. $\mathrm{PhD}$ thesis.

Chaves MM, Pereira JS, Maroco J, Rodrigues ML, Ricardo CPP, Osório ML, Carvalho I, Faria T, Pinheiro C (2002) How plants cope with water stress in the field. Photosynthesis and growth. Ann. Bot. 89:907-916.

Cornic G (2000) Drought stress inhibits photosynthesis by decreasing stomatal aperture - not by affecting ATP synthesis. Trends Plant Sci. 5:187-188.

Dutra RC (1987) Fenologia de dez espécies arbóreas nativas do cerrado de Brasília - DF. Bra. Flor. 62:23-41.

Eamus D, Myers B, Duff G, Williams D (1999) Seasonal changes in photosynthesis of eight savanna tree species. Tree Physiol. 19:665-671.

Edelman GM, Gally JA (2001). Degeneracy and complexity in biological systems. Proc. Nat. Acad. Sci. USA 98:1376313768.

Ehleringer JR (1995) Variations in gas exchange characteristics among desert plants. In: Schulze, E-D, Caldwell, MM (eds), Ecophysiology of photosynthesis. pp 361-392. Springer, New York, USA.

Ferri MG (1944) Transpiração de plantas permanentes dos cerrados. Botânica 4:161-224.

Ferri MG (1955) Contribuição ao conhecimento da ecologia do cerrado e da caatinga. Estudo comparativo do balanço hídrico de sua vegetação. Botânica 12:1-170.

Franco AC (1998) Seasonal patterns of gas exchange, water relations and growth of Roupala montana, an evergreen savanna species. Plant Ecol. 136:69-76.

Franco AC (2002) Ecophysiology of woody plants. In: PS Oliveira and RJ Marquis (eds), The cerrados of Brazil: Ecology and natural history of a neo-tropical savanna. pp. 178-197. Columbia University Press, Irvington.

Franco AC, Nardoto GN, Souza M (1996) Patterns of soil water potential and seedling survival in cerrado of central Brazil. In: Annals of the VIII Simpósio sobre o cerrado. Brasília, Brasil, pp. 227-280.

Gardner MR, Ashby WR (1970). Connectance of large dynamic (cybernetic) systems: critical values for stability. Nature 228:784.

Goodland RJA, Ferri, MG (1979) Ecologia do Cerrado. Itatiaia, Belo Horizonte.

Grisi BM (1971) Contribuição ao conhecimento de Ecologia Vegetal do Cerrado. Balanço hídrico de dois espécimes de Ouratea spectabilis (Mart.) Engl. In: Annals of the III Simpósio sobre o cerrado. São Paulo, Brasil, pp.86-89.

Hare PD, Cress WA, Van Staden J (1998) Dissecting the roles of osmolyte accumulation during stress. Plant Cell Environ. 21:535-553.

Johnson C, Franco, AC, Caldas, LS (1983). Fotossíntese e resistência foliar em espécies do cerrado: metodologia e resultados preliminares. Rev. Bras. Bot. 6:91-97. 
Jones HG (1992) Plants and microclimate: A quantitative approach to environmental plant physiology. Cambridge University Press, Cambridge.

Jones HG (1998) Stomatal control of photosynthesis and transpiration. J. Exp. Bot. 49: 387-398.

Larcher W (2003) Physiological Plant Ecology. Springer Verlag, Berlin-Heidelberg.

Manly BFJ (1994) Multivariate statistical methods. Chapman \& Hall, London.

Mattos EA, Reinert F, Moraes JAPV (1997) Camparison of carbon isotope discrimination and $\mathrm{CO}_{2}$ and $\mathrm{H}_{2} \mathrm{O}$ gas exchange between the dry and wet seasons in leaves of several cerrado woody species. Rev. Bras. Fisiol. Veg. 9:77-82.

Meinzer FC, Goldstein G, Franco AC, Bustamante M, Igler E, Jackson P, Caldas LS, Rundel PW (1999) Atmospheric and hydraulic limitations on transpiration in Brazilian cerrado woody species. Func. Ecol. 13:273-282.

Mendonça RC, Felfili JM, Walter BMT, Silva Jr MC, Rezende AB, Filgueiras TS, Nogueira PE (1998) Flora vascular do cerrado. In: Sano SM, Almeida SP (eds), Cerrado, Ambiente e Flora, pp. 289-556. EMBRAPA, Planaltina, Brasil.

Moraes JAPV, Perez, SCJGA, Carvalho LF (1989) Curso diário e sazonal do potencial da água e da resistência estomática em plantas de um Cerradão. Ann. Missou. Botanic. Gard. 27:13-23.

Moraes JAPV, Prado CHBA (1998) Photosynthesis and water relations in Cerrado vegetation. Oecol. Brasilien. 4:45-63.

Naves-Barbiero C, Franco AC, Bucci SJ, Goldstein G (2000) Fluxo de seiva e condutância estomática de duas espécies lenhosas sempre verdes no campo sujo e cerradão. Rev. Bras. Fisiol. Veg. 12:119-134.

Nix HA (1983) Climate in tropical savanna. In: Bourliere F (ed), Ecosystems of the world, tropical savanna, pp 3762. Elsevier Scientific Publishing Company, Amsterdam, The Netherlands.

Nobel PS (1999) Physicochemical and environmental plant physiology. Academic Press, San Diego.

Oliveira PE (1998) Fenologia e biologia reprodutiva das espécies de cerrado. In: Sano SM, Almeida SP (eds), Cerrado, ambiente e flora, pp. 169-192. EMBRAPA, Planaltina, Brasil.
Paula NF (2002) Capacidade fotossintética, deciduidade e teor de nitrogênio e fósforo em espécies lenhosas do cerrado. São Carlos, Universidade Federal de São Carlos. PhD thesis.

Perez SCJGA, Moraes, JAPV (1991) Determinações de potencial hídrico, condutância estomática e potencial osmótico em espécies dos estratos arbóreo, arbustivo e herbáceo de um cerrado. Rev. Bras. Fisiol. Veg. 3:27-37.

Prado CHBA, Moraes, JAPV (1994) Gas exchange and leaf water status in potted plants of Copaifera langsdorffii Desf. 2 - Probable influence of low air humidity. Photosynthetica 31:31-36.

Prado CHBA, Moraes, JAPV (1997) Photosynthetic capacity and leaf specific mass in twenty woody species of cerrado vegetation. Photosynthetica 33:103-112.

Prior LD, Eamus D, Duff GA (1997) Seasonal and diurnal patterns of carbon assimilation, stomatal conductance, and leaf water potential in Eucalyptus tetrodonta Saplings in a wet-dry savanna. Aust. J. Bot. 45:241-258.

Ratter JA, Ribeiro JF, Bridgewater S (1997) The Brazilian cerrado vegetation and threats to its biodiversity. Ann. Bot. 80:223-230.

Rawitsher F (1948) The water economy of the campos cerrados in Southern of Brasil. J. Ecol. 36:237-268.

Rizzo JA, Centeno AJ, Santos-Lousa J, Filgueiras TS (1971) Levantamento de dados em área de Cerrado e da Floresta Caducifólia Tropical do planalto centro-oeste. In: Ferri MG (ed), III Simpósio sobre cerrado, pp. 103-110. Editora Edgar Blücher, São Paulo, Brasil.

Sokal RR, Rohlf, FJ (1981) Biometry. Freeman, San Francisco.

Souza GM, Ribeiro RV, Santos MG, Ribeiro HL, Oliveira RF (2004) Functional groups of forest succession as dissipative structures: an applied study. Braz. J. Biol. 64(4): (in press)

Tolentino M (1967) Estudo crítico sobre o clima da região de São Carlos. Prefeitura Municipal de São Carlos, São Carlos.

Trewavas A (1986) Understanding the control of plant development and the role of growth substances. Aust. J. Plant Physiol. 13:447-457.

Williams RJ, Myers BA, Muller WJ, Duff GA, Eamus D (1997) Leaf phenology of woody species in a North Australian tropical savanna. Ecology 78:2542-2558. 